
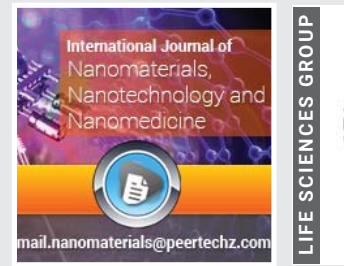

Nanomaterials, Nanotechnology and Nanomedicine

Review Article

\title{
A Review on Gold
}

\section{Nanoparticles (GNPs) and their Advancement in Cancer}

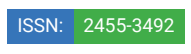

\section{DOl:} Therapy

Received: 26 December, 2020

Accepted: 12 January, 2021

Published: 19 January, 2021

*Corresponding author: Muhammad Amjad, Department of Chemistry, Lahore Garrison University, Lahore, Pakistan, E-mail: e-mail: amjadqcm@gmail.com

Keywords: Gold nanoparticles; Radiation; Drug delivery system; Chemo radiotherapy

https://www.peertechz.com

Check for updates

\section{Shabbir Hussain and Muhammad Amjad*}

Department of Chemistry, Lahore Garrison University, Lahore, Pakistan

\begin{abstract}
There are approximately 18 million cancer cases have been observed per year worldwide according to Global cancer therapy (GLOBOCAN). Chemotherapy, radiotherapy and surgery have been mostly used for cancer therapy. The maximum tolerated dose is currently being used to cure patients. The incorporated advancement of modern nanoparticle-based techniques will be important to find one of the main issues in both radiotherapy and chemotherapy: normal tissue toxicity. The Gold Nanoparticle (GNP) based systems are very helpful to further improve chemotherapy by controlled releases of chemotherapeutics, but local radiotherapy dose can be improved through targeting the GNPs to the tumor. Over 20 nanotechnology-based therapeutic products have been authorized for clinical use in the past two decades. The main purpose of this review article is to understand how we can accelerate the clinical use of GNP-based therapeutic system to reduce normal tissue toxicity while increasing the worth of the treatment. Nanomedicines will change future cancer treatment methods in a better way that has minimum side effects.
\end{abstract}

\section{Introduction}

The progress in the fictionalization of chemistry with innovative NPs and their differentiated uses in the cure of several human infections have focused worldwide [1]. Nanotechnology is vital for the delivery of drug materials, with numerous dormant uses in medical prescription and investigation. The extensive uses of NPs in areas of nanomedicine are vast, for example, cancer therapy, investigative methods and also for medicinal resolutions [2]. The selection of NPs for cancer therapy is extremely preferred by their distinctive physicochemical features that grip for future improvement of cure of infections in cancer therapy with negligible reverse influences. NPs units used in nanotechnology having size ranges between $1.0 \mathrm{~nm}$ to $100 \mathrm{~nm}$ and possess completely innovative or progressive possessions because of their higher size to volume ratio [3].

Metal NPs are the focus of investigation determinations as new platform for cancer therapy to a specified target sites. Nano carriers are innovative tools for cancer in therapy specific target sites. Over the centuries, numerous distribution resources were intended built on diverse NPs, such as nano polymers, NPs liposomes, nano dendrimers, nanorods, and nano-tubes. Different nanoparticles that are used in the treatment of targeted cancer shown in Figure 1. Innovations in nanotechnology assure to renovate synthesis of drugs, drug delivery, and clinical trials.

By knowing how the materials work perversely at a particular cell or component, investigators are exposing the huge therapeutic potential of nanoscale approaches [4]. Though the plentiful study is quiet in its initial periods, researchers and investigators are producing innovative tools and evolving novel approaches for fundamental study areas for the synthesis of

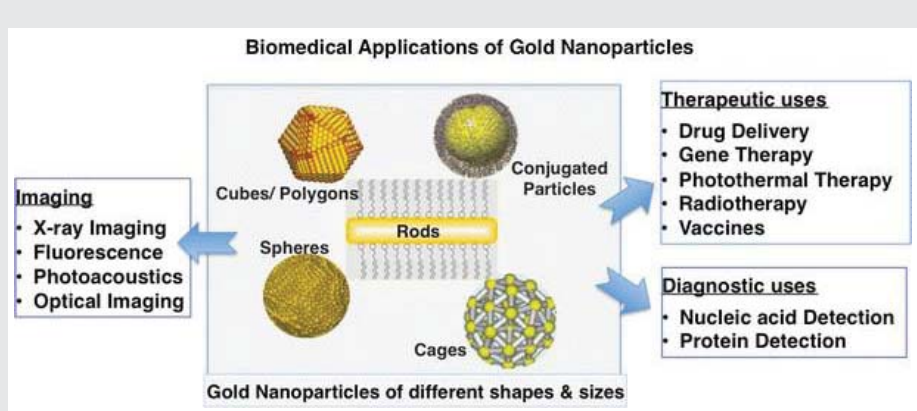

Figure 1: Biomedical applications and different shapes of GNPs [14]. 
the drug, drug carriers, target indications, reduction in toxicity, and tools optimization $[5,6]$.

Nanoparticles, especially those of gold find a special scope in cancer therapy. It has been accounted for likewise that GNPs have special synthetic and somatic features for carrying and releasing therapeutic agents $[7,8]$. The primary favorable position of GNPs as a medication transporter is that the gold center is basically latent and non-dangerous; additionally, the selection of GNPs is supported with blending ease and their position of functionalization, by and large, completes thiol links. Most prominently, from their photograph, somatic features can activate medication discharge [9] at a remote spot.

\section{Gold Nanoparticles (GNPs)}

Gold is one of the first metals that have been exposed. The account of investigation and scope of Gold periods however some thousand years. Early evidence on colloidal gold may initiate in treatises by Arabic scientists, Chinese researchers, as well as Indian investigators, who worked to achieve the colloidal gold as timely as in the fifth-fourth eras. The scientists used colloidal gold for therapeutic and further purposes. In Europe, colloidal gold was investigated and applied in all chemistry research centers.

Functionalized Gold Nanoparticles (GNPs) with organized optical as well as geometrical characteristics are focused in research works used in medical fields including biosensors, different immune systems, experimental clinical sciences, genomics, laser therapy of tumors and cancer cells, drug delivery, antigens and DNA, scanning, imaging and control of cancer cells and cancer tissues with the usage of state-of-art indication methods [10].

However, GNPs have been acknowledged as an attractive candidate for the delivery of drug particles to detected target cells. The receiving of GNPs as an outstanding candidate for delivery of therapeutic agents was due to its exceptional possessions particularly in transportation and release of drug to its target cells. Therapeutic particles delivered must be significantly smaller in size embedded in drug particles or in large biomolecules, for example, amino acids, nucleic acids, RNA, or DNA and efficiency of their discharge at the site is essential for effective treatment [11].

GNPs, usually have an extraordinarily higher surface-tovolume ratio, due to biocompatibility and inertness, and can be certainly functionalized with numerous other functional groups; so, they can also play a key role in the medical field as adjuvant, reducing the toxic effects, increasing the immunogenic effects, and offering the storage stability of medicines and other drugs related to vaccinations, and also possess the excessive potential [12].

The GNPs have been become of greatest popularity due to their effectiveness in cancer therapy and drug delivery. GNPs had established their own way from finding to therapy in current day's drugs possess the basis of functional moieties and their proficiencies in the distribution of amino acids, protein, nucleic acid, and gene therapy in vivo cure and symptoms
[12]. For biomedical uses, outer functionalization of GNPs is essential so as for making the GNPs to explicit sickness zones, enabling to specifically interface with other cell or biomolecule. The subsequent GNPs posses interesting characteristics [3], for example, measure and figure-subordinate visual and electronic attributes, a high surface zone to sum proportion, and surfaces that can be quickly changed with the ligands holding valuable assemblies, for example, amines, phosphines, and thiols, which display a preference for gold faces [14]. By methods for these practical gatherings to attach the ligands, extra moieties like antibodies, amino acids, proteins, and dinucleotides are utilized to report the prevalent usefulness [4]. The wide scope of use for GNPs depends on exceptional somatic as well as synthetic characteristics. Specifically, optical features of GNPs are controlled with their surface plasmon vibrations [2], which relates with joined excited conductive electrons and confined within a wide region, from noticeable to infrared (IR) area, contingent upon size, shape and the structure of molecule. In Figure 1 different shapes of GNPs and their applications have been explained.

\section{Methods for the synthesis of gold nanoparticles}

Generally, the following methods have been followed for the synthesis of gold nanoparticles (GNPs):

Chemical methods: A well known Turkevich method is the type of chemical method mostly used to synthesize the GNPs and very promising method as compared to others. In this technique, $\mathrm{Au}^{+3}$ ions are reduced by mild reducing agent like citrate [15], ascorbic acid [16], and tannic acid [17]. The biocompatible and small size GNPs are synthesized by Turkevich method as shown in Figure 2. It is necessary to control the parameters such as $\mathrm{pH}$, temperature and concentration for the synthesis of GNPs during this process [18]. In 1944, the Brust-Schiffrin method was introduced by Brust and Schiffrin. This method is easy to synthesize the thermally stable and airstable GNPs of controlled and low dispersity. In this method, $\mathrm{AuCl}_{4}$ was shifted to toluene from an aqueous using, tetraoctylammonium bromide (TOAB) as the phase-transfer and reduced by $\mathrm{NaBH}_{4}$, in the presence dodecanethiol. The use of reducing agents changes the color of organic phase from orange to deep brown [19].
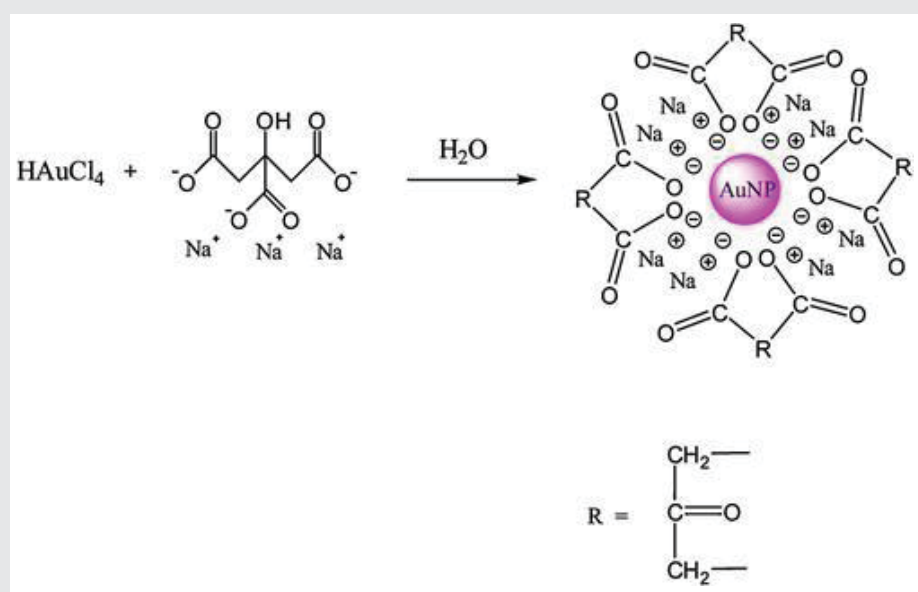

Figure 2: Schematic diagram for the synthesis of gold nanoparticles by Turkevich method. 
Seeding growth method is another method for the synthesis of GNPs of diameter 5-40 nm and narrow size distribution. The particles size can be controlled by altering the ratio of seed to metal salts and hence the particles of 5-40 nm can be prepared [20]. This method has advantages due to a quick, simple and cost-effective [21].

Biological methods: Chemical methods are the most common techniques used for the synthesis of metallic nanoparticles. The cost of reducing agents and stabilizing agents limits their applications. Furthermore, the prepared nanoparticles by chemical methods may have toxic consequences in biomedical applications [22]. So, there is a requirement to develop easy and cost-effective procedures for the synthesis of nanoparticles that do not consume any toxic chemicals. The synthesis of nanoparticles by biological methods in current years has become the center of attention as green and eco-friendly methods. In biological methods, the synthesis of nanoparticles usually carried out by microorganisms, plants or plant extracts and enzymes [23]. In recent times, the use of plants for the synthesis of nanoparticles is preferred, because of less toxic, cost-effective and eco-friendly. The biosynthesis of nanoparticles in recent years by means of plants such as Azadirachta indica [22], Aloe Vera [24], Medicago sativa [25], Cinnamomum camphora [26], Coriandrum sativum [27], Pelargonium graveolens [22], Terminalia catappa [28], and lemongrass [22] have been used.

The synthesis of GNPs by the use of plant extracts such as Memecylon umbellatum [29], Citrus limon, Citrus reticulata and Citrus sinensis [30], Memecylon edule [31], Terminalia chebula , Nyctanthes arbor-tristis [32], Mangifera indica [33], Cinnamomum zeylanicum [34], Piper pedicellatum [35], Cochlospermum gossypium [36], Brevibacterium casei [37] and Macrotyloma uniflorum [38].

Using the extract of Zingiber officinale GNPs can be synthesized in the range of $5-15 \mathrm{~nm}$. Zingiber officinale plays a dual role as a reducing and stabilizing agent in the synthesis of GNPs [39]

\section{Cancer therapy}

In the last several years, great development in synthesis and applications of GNPs have been achieved for cancer treatment. GNPs are particularly appropriate to destruct the cancer cells thermally due to their surface activation and heating capability photothermally [1]. Tumor nanoscience is a multidisciplinary field with extensive possible uses in the treatment of cancer, with cancer cell diagnosis, molecular-imaging, bio-informatics, and target therapy [40]. Conventional approaches for tumortherapy include the chemo-therapy, radiation treatment, and surgical treatment. The development of specialized GNPs for use in finding and cure of cancer is increasing, due to their specific properties [41] like their ability to interact with different drugs, retention in tumor tissues, light absorbance in near-infrared light and their interaction with radiations [42]. GNPs particularly have greatly focused on for cancer research in previous years due to their simplistic fabrication as well as surface variations, greatly improved and changeable optical features including outstanding biocompatibility for clinical approaches [43].

As a developing idea that enables instantaneous prediction and cure, the execution of therapeutic NPs bear the strong potential for enhanced tumor therapy and decreased negative influences [12]. GNPs are used in cancer treatment, due to their specific properties, like their ability to interact with different drugs, retention in tumor tissues, light absorbance in IR light and their contact with radiations. Having the advantages of their exclusive features, several types of research of cancer treatment by GNPs have been applied photo-thermally to destruct the tumor cell or tissues which may contain the potential for clinical use [44]. When the cancer cells are bombarded with focused laser light of appropriate wavelength, GNPs can destruct the structure of bacterial cells and tumor tissues [45].

For effective application of GNPs in the treatment of cancer, gold nanostructure must contain biocompatibility and display superiorpointing of tumor cells over healthy cells [46]. For active tumor therapy, gold-based NPs can be fabricated to particularly to district the tumor tissues and reduce side effects for healthy cells. Numerousmethods are applied to improve cancer cell targeting, cellular intake for effective cancer treatment, as well as, methods which are usually classified into two classes which are active target method and passive target method.

The passive target method depends on the passive growth of GNPs within the cancer area because of the Enhanced Permeability Retention (EPR) mechanism [47]. Several ligand molecules have utilized in trials to enhance cancer cell destruction via particular molecular reactions including proteins, antibodies, nucleic acids, hormones and small molecules. Usually, these approaches depend on the contact of GNPs ligand and related parts of cancer tissues [46].

When GNPs are placed close to each other, they display exhibit various surface plasmon resonances. Thus, they can differentiate between cancerous and normal cells when conjugated to anti-epidermal growth factor receptor antibodies as a biomarker agent [47]. It has been predicted 24.6 million individuals are surviving and they achieved treatment of cancer disease in previous five years. About half of individuals are affected by this disease each year achieve radiotherapy during their cure process. Carrying a therapeutic dosage of radiations to destruct the cancer cells whereas saving the healthy cells is still a strong task in radiotherapy approaches. The idea of applying high material to enhance dosage form to cancer cells while applying radiotherapy was developed over twenty years before as iodine salt utilized for the sensitization of cell cultures.

\section{Chemotherapy}

The adance and sucessful treatment of tumor therapy is a big challenge because of low specificty of the drug and lethal consequence on neighboring non- tumour cells. A specific targeting treatment depends on the exact delivery of an active 
drug to the target by using various suitable affinity reagents like as those mediated by a ligand-receptor, lecithin-carbohydrate or antigen-antibody recognition [49].

Conservative chemotherapy is actually influensive but also famous due to its severe bad impacts due to somewhat random endorsement of chemotherapeutic agents into healthy cells as well as into malignant cells in tissue and organ systems [50]. Major enhancement has been established in latest years with the beginning of nano-size medicines, that provide a significant association with chemotherapy as a novel drug.

\section{Radiotherapy}

Radiotherapy is the main therapy and is valuable to cure around $50 \%$ of all types of cancer infected. The cure depends on the deposition of drug dose in cancer cells, usually by the bombardment of either gamma radiations or high energy $\mathrm{X}$-rays or by a beam of high energy ions which may enough to irradiate the tumor cells or either their cell membrane and finally cause their death [45]. Furthermore, the use of NPs in nanosize drugs, that have effectively enhanced therapeutic action, is the characteristic of recent chemotherapeutics in current years. The impact of the GNPs in the development of chemotherapeutic efficacy is determined by the dose enhancement factor (DEF). The DEF of GNPs is well-defined as "fraction of chemotherapeutic drug intake by cancer cells in the availability of GNPs to the fraction of drug intake by the cancer cells in lack of GNPs".It can alter with quantity and effectiveness of GNPs and their site inside infected cells. Gold Nanoparticles (GNPs) have may advantages because they possess straightforward synthesis, good biocompatibility, wide range sizes, simple and easy functionalization by the attachment of ligands neeeded to target cancer cells and their organelles or better life time in the blood stream [51].

\section{Hyperthermia}

It has been newly announced as a modern treatment method for tumor cells and has great potential to fight this infection. It can be defined as a cure method in which infected cells are exposed to a higher temperature which either terminates cancer cells [52]. This rise in temperature of cancer cells alters vascular penetrability, enhances the flow of current and ultimately leads to cancer oxygenation [12]. Hence, hyperthermia alleviates tissue hypoxia and could be concurrently applied with radioactive drugs or anticancer drugs to increase their cytotoxic impacts on cancer. In old hyperthermia, the site of the individual body having cancer is heated to a temperature of $40-45^{\circ} \mathrm{C}$, some degrees beyond physical temperature [47]. Heat is produced outside by means of tools that generates electromagnetic radiations or ultrasound radiations [53]. Traditional hyperthermia is applied combined with chemotherapy as well as radiation treatment mechanism, for the treatment of different kinds of cancers in numerous clinical applications [12]. The heat produced from gold- based NPs can be applied in cancer treatment to destruct tumor tissues.

The variation between traditional photo-thermal treatment mechanism [54] and hyperthermia is a heat treatment that may happen photothermally in the area of gold-based NPs, and cell temperature can raise up to hundred of centigrade over body temperature [43]. It has been suggested that photothermal heat treatment can be further effective to cancer cells instead of healthy cells to overcome the bad impacts of cancer treatment methods [55]. Traditionally, hyperthermia is applied, in association with radiotherapy as well as chemotherapy, for the extermination of a diversity of cancer categories in numerous experimental tests. The heat produced from GNPs is used in cancer therapy to stop the growth of tumor cells. The difference between traditional [52] and photo-thermal treatment is that photo-thermal treatment only occurs in zone straight about GNPs, and limited temperature $=-098$ nges can raise to a hundred degree over physical temperature. It indicates photo-thermal therapy can more target cancer cells somewhat healthy tissues to potentially decrease the bad impacts of cancer treatments [6].

\section{General applications of gold naoparticles}

Gold nanoparticles as drug delivery agents to targeted cancer cells: GNPs are the best nanocarriers for therapeutic due to their ease of synthesis, functionalization and biocompatibility [56]. In cancer therapy, GNPs are corrently used as potential drug delivery mediators for introduction into tumor cells [57]. The cells take up colloidal gold nanoparticles of different sizes and shapes [58] through ligandreceptor interaction or nonspecific means. In order to confirm the specific destruction of cancer cells, gold nanoparticles are conjugated with suitable surface ligands which directed them only to tumor cells as shown in Figure 3.

There are two methods for tumor targeting that have been described: the first concerned the conjugation of AuNPs to Polyethylene glycol (PEG) and the second involved the conjugation of AuNPs with a specific antibody that binds distinctive biomarkers indicated on tumor cells. PEG inhibited GNPs agglutination and increasesd the retention in blood. The accumulation of AuGNPs in tumor cells due to the high permeability of poorly differentiated blood vessels around tumors as described in Figure 4 .

Drug delivery systems (DDSs) give good attributes to a "free" drug by enhancing solubility, in vivo stability, and biodistribution. They can also change the bad pharmacokinetics

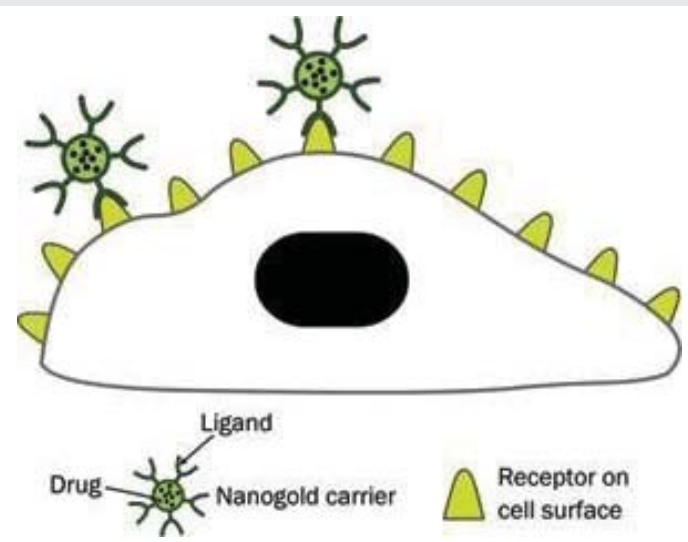

Figure 3: GNPs carriers with anticancer cells and ligands [59].

Citation: Hussain S, Amjad M (2021) A Review on Gold Nanoparticles (GNPs) and their Advancement in Cancer Therapy. Int J Nanomater Nanotechnol Nanomed 
of certain "free' drugs. Further, large loading of pharmaceuticals on DDSs can render ' drug reservoir, for restricted and sustained release to sustain the drug level within the therapeutic window $[60]$.

\section{Gold nanoparticles applications in biosensor}

A biosensor has been designed by g1old nanoparticles that are functionalized with a thiolated biomolecule that causes a change in the optical absorption of GNPs after identifying the complementary biomolecules. Gold nanoparticles functionalized with antigen (antibody) combined when matching antibody (antigen) binds as a result cause change in the Plasmon absorption [61].

\section{Gold nanoparticles applications for immunosensors}

In the lateral flows immunosensing (LFIS) method, colloidal GNPs are the most widespread choice of the nanoparticles. LFIS approach depends upon the immunological reactions in which an antigen is sensed through a specific antibody tagged with different markers like GNPs, latex beads. LIFS is categorized as quantitative, qualitative and semi-quantitative depend on the type of detection [62].

Immunosensors have excellent limit of detection of small analyte volumes. A new and sensible electrochemical immunoassay for immunoglobulin (IgG) is using a colloidal gold by anodic stripping voltammetry technique. A new electrochemical immunoassay of the precipitation of silver on colloidal gold labels has been described in Figure 5 .

The sensitivity is increased for electrochemical immunoassay by the autocalytic deposition of $\mathrm{Au}^{+3}$ onto GNPs.

\section{Conclusion}

The use of Gold Nanoparticles (GNPs) provides a better opportunity for the treatment of cancer in various parts of the human body. GNPs play a key role in the medical field as an adjuvant, reducing the toxic effects, increasing the immunogenic effects, and offering the storage stability of

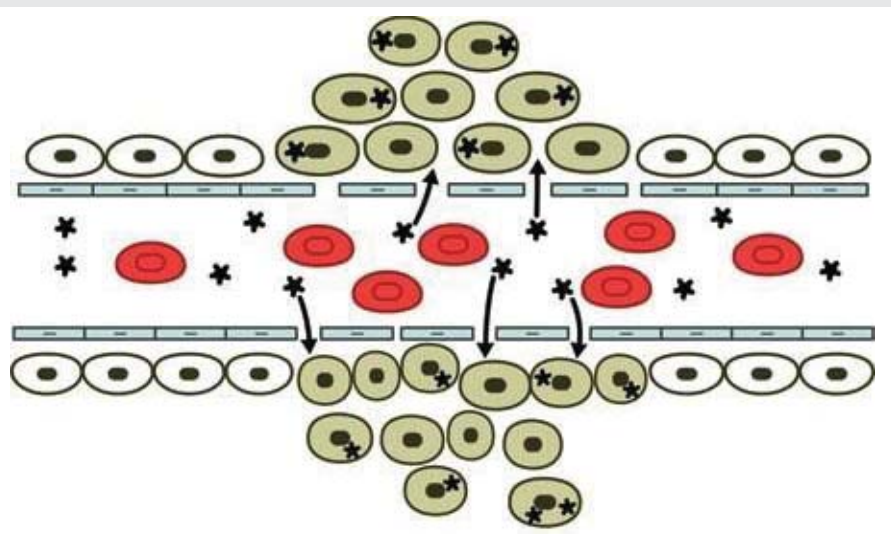
(-) Normal cell
Red blood cell
Cancer cell
* AuNP-PEG conjugated with antibodies

Figure 4: Accumulation of ligand-targeted gold nanoparticles conjugated with anticancer drugs in cancer cells [59].

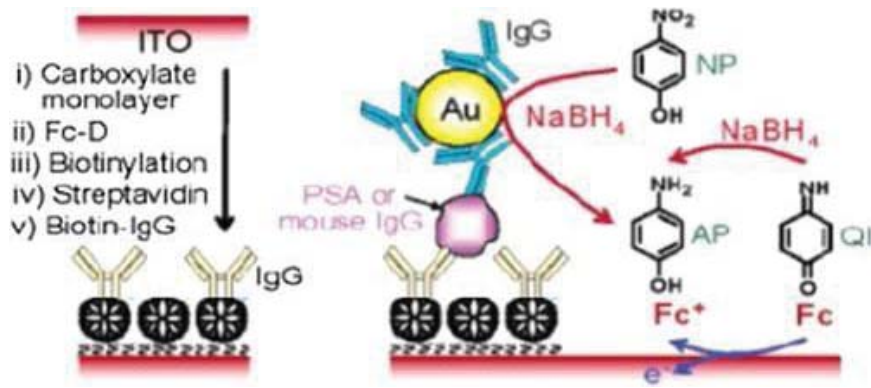

Figure 5: Gold nanoparticles for immunosensors [63]

medicines and other drugs related to vaccinations, and also possess excessive potential. Functionalized Gold Nanoparticles (GNPs) are also used in various medical technology including biosensors, different immune systems, experimental clinical sciences, genomics, laser therapy of tumors and cancer cells, drug delivery, antigens and DNA scanning, imaging and control of cancer cells. The main purpose of this article to focus on the issues that have been faced in the past during cancer therapy like targeted therapy, and the combination of chemotherapy and radiotherapy. Hence, gold nanoparticle (GNP) based systems are very helpful to further improve chemotherapy by controlled releases of chemotherapeutics.

\section{Acknowledgments}

The authors are grateful to highly regarded Dr. Shabbir Hussain for his collaboration to compile this work. There are no funding sources are available from any organization/ Agency/Institution, etc.

\section{References}

1. Abadeer NS, Murphy CJJT (2016) Recent progress in cancer thermal therapy using gold nanoparticles. 120: 4691-4716. Link: https://bit.ly/3su55Tw

2. Aioub M, Austin LA, El-Sayed MA (2018) Gold nanoparticles for cance diagnostics, spectroscopic imaging, drug delivery, and plasmonic photothermal therapy. Inorganic Frameworks as Smart Nanomedicines Elsevier 41-91. Link: http://bit.ly/38KP6sH

3. Catherine L, Olivier P (2017) Gold nanoparticles for physics, chemistry and biology: World Scientific.

4. Beik J, Abed Z, Ghoreishi FS, Hosseini-Nami S, Mehrzadi S, et al. (2016) Nanotechnology in hyperthermia cancer therapy: From fundamenta principles to advanced applications. J Control Release 235: 205-221. Link: http://bit.ly/3srFzhR

5. Brown SD, Nativo P, Smith JA, Stirling D, Edwards PR, et al. (2010) Gold nanoparticles for the improved anticancer drug delivery of the active component of oxaliplatin 132: 4678-4684. Link: https://bit.ly/38KAKIH

6. Brown SD, Nativo P, Smith JA, Stirling D, Edwards PR, et al. (2010) Gold nanoparticles for the improved anticancer drug delivery of the active component of oxaliplatin 132: 4678-4684. Link: https://bit.ly/38KAKIH

7. Jazayeri $\mathrm{MH}$, Amani $\mathrm{H}$, Pourfatollah $\mathrm{AA}$, Pazoki-Toroudi $\mathrm{H}$, Sedighimoghaddam BJS, et al. (2016) Various methods of gold nanoparticles (GNPs) conjugation to antibodies. Sensing and Bio-Sensing Research 9: 17-22. Link: http://bit.ly/3nISWXh

8. Yang X, Liu X, Liu Z, Pu F, Ren J, et al. (2012) Near-infrared light-triggered, targeted drug delivery to cancer cells by aptamer gated nanovehicles. Adv Mater 24: 2890-2895. Link: http://bit.ly/2KeUFpF

Citation: Hussain S, Amjad M (2021) A Review on Gold Nanoparticles (GNPs) and their Advancement in Cancer Therapy. Int J Nanomater Nanotechnol Nanomed 7(1): 019-025. DOI: https://dx.doi.org/10.17352/2455-3492.000040 
9. Wust P, Hildebrandt B, Sreenivasa G, Rau B, Gellermann J, et al. (2002) Hyperthermia in combined treatment of cancer. Lancet Oncol 3: 487-497. Link: http://bit.ly/2XIAuDG

10. Cabuzu D, Cirja A, Puiu R, Mihai Grumezescu AM (2015) Biomedical applications of gold nanoparticles. Curr Top Med Chem 15: 1605-1613. Link: http://bit.ly/3nRTV7W

11. Cai W, Gao T, Hong H, Sun J (2008) Applications of gold nanoparticles in cancer nanotechnology. 1: 17-32. Link: http://bit.ly/2LFJ2su

12. Carabineiro CAS (2017) Applications of gold nanoparticles in nanomedicine: recent advances in vaccines. Molecules 22: 857. Link: http://bit.ly/3806WuR

13. Herizchi R, Abbasi E, Milani M, Akbarzadeh A (2016) Current methods fo synthesis of gold nanoparticles. Artif Cells Nanomed Biotechnol 44: 596-602. Link: http://bit.ly/2XJYMNJ

14. Zhang X (2015) Gold Nanoparticles: Recent Advances in the Biomedical Applications. Cell Biochem Biophys 72: 771-775. Link: https://bit.ly/3qyBIDn

15. Kimling J, Maier M, Okenve B, Kotaidis V, Ballot H, et al. (2006) Turkevich method for gold nanoparticle synthesis revisited. The J Phys Chem B 110 15700-15707. Link: https://bit.ly/2M46oYV

16. Larm NE, Essner JB, Pokpas K, Canon JA, Jahed N, et al. (2018) Roomtemperature turkevich method: formation of gold nanoparticles at the speed of mixing using cyclic oxocarbon reducing agents. J Phys Chem C 122 51055118. Link: https://bit.ly/38WyCOf

17. Ahmad T (2014) Reviewing the tannic acid mediated synthesis of metal nanoparticles. Journal of Nanotechnology. Link: https://bit.ly/3sB91|J

18. Hussain MH, Bakar NFA, Mustapa AN, Low KF, Othman NH, et al. (2020) Synthesis of Various Size Gold Nanoparticles by Chemical Reduction Method with Different Solvent Polarity. Nanoscale Research Letters 15: 1-10. Link: Link: https://bit.ly/3nQEQmY

19. Brust M, Walker M, Bethell D, Schiffrin DJ, Whyman R (1994) Synthesis of thiolderivatised gold nanoparticles in a two-phase liquid-liquid system. Journal of the Chemical Society, Chemical Communications 801-802. Link: https://rsc.li/3sEjVHq

20. Jana NR, Gearheart L, Murphy CJ (2001) Seeding growth for size control of 5- $40 \mathrm{~nm}$ diameter gold nanoparticles. Langmuir 17: 6782-6786. Link: https://bit.ly/2M0TxXt

21. Siti RM, Khairunisak AR, Aziz AA, Noordin R (2013) Green synthesis of $10 \mathrm{~nm}$ gold nanoparticles via seeded-growth method and its conjugation properties on lateral flow immunoassay. Paper presented at the Advanced Materials Research.

22. Shankar SS, Rai A, Ankamwar B, Singh A, Ahmad A, et al. (2004) Biological synthesis of triangular gold nanoprisms. Nature Materials 3: 482-488. Link: https://go.nature.com/3isEnq8

23. Mohanpuria P, Rana NK, Yadav SK (2008) Biosynthesis of nanoparticles: technological concepts and future applications. Journal of Nanoparticle Research 10: 507-517. Link: https://bit.ly/3ixmp5F

24. Chandran SP, Chaudhary M, Pasricha R, Ahmad A, Sastry M (2006) Synthesis of gold nanotriangles and silver nanoparticles using Aloevera plant extract. Biotechnol Prog 22: 577-583. Link: https://bit.ly/38XMaJc

25. Gardea-Torresdey J, Parsons J, Gomez E, Peralta-Videa J, Troiani H, et al. (2002) Formation and growth of Au nanoparticles inside live alfalfa plants. Nano letters 2: 397-401. Link: https://bit.ly/2LATjqb

26. Huang J, Li Q, Sun D, Lu Y, Su Y, et al. (2007) Biosynthesis of silver and gold nanoparticles by novel sundried Cinnamomum camphora leaf Nanotechnology 18: 105104. Link: https://bit.ly/2LJnVpn

27. Narayanan KB, Sakthivel N (2008) Coriander leaf mediated biosynthesis of gold nanoparticles. Materials Letters 62: 4588-4590. Link: https://bit.ly/2NlkaXP

28. Ankamwar B (2010) Biosynthesis of gold nanoparticles (green-gold) using leaf extract of Terminalia catappa. E-Journal of Chemistry 7. Link: https://bit.ly/3qx7hYL

29. Arunachalam KD, Annamalai SK, Hari S (2013) One-step green synthesis and characterization of leaf extract-mediated biocompatible silver and gold nanoparticles from Memecylon umbellatum. Int J Nanomedicine 8: 13071315. Link: https://bit.ly/3ioGPh8

30. Sujitha MV, Kannan S (2013) Green synthesis of gold nanoparticles using Citrus fruits (Citrus limon, Citrus reticulata and Citrus sinensis) aqueous extract and its characterization. Spectrochim Acta A Mol Biomol Spectrosc 102: 15-23. Link: https://bit.ly/38WfShV

31. Elavazhagan T, Arunachalam KD (2011) Memecylon edule leaf extract mediated green synthesis of silver and gold nanoparticles. Int J Nanomedicine 6: 1265. Link: https://bit.ly/3sB9DYz

32. Das RK, Gogoi N, Bora U (2011) Green synthesis of gold nanoparticles using Nyctanthes arbortristis flower extract. Bioprocess Biosyst Eng 34: 615-619. Link: https://bit.ly/3bRdqeh

33. Philip D (2010) Rapid green synthesis of spherical gold nanoparticles using Mangifera indica leaf. Spectrochimica Acta Part A: Molecular and Biomolecular Spectroscopy 77: 807-810. Link: https://bit.ly/38WEPcZ

34. Smitha S, Philip D, Gopchandran K (2009) Green synthesis of gold nanoparticles using Cinnamomum zeylanicum leaf broth. Spectrochimica Acta Part A: Molecular and Biomolecular Spectroscopy 74: 735-739. Link: https://bit.ly/3sBy9bW

35. Tamuly C, Hazarika M, Borah SC, Das MR, Boruah MP (2013) In situ biosynthesis of $\mathrm{Ag}, \mathrm{Au}$ and bimetallic nanoparticles using Piper pedicellatum C. DC: green chemistry approach. Colloids Surf B Biointerfaces 102: 627-634 Link: Link: https://bit.ly/3sAfAot

36. Vinod V, Saravanan P, Sreedhar B, Devi DK, Sashidhar R (2011) A facile synthesis and characterization of $\mathrm{Ag}, \mathrm{Au}$ and $\mathrm{Pt}$ nanoparticles using a natura hydrocolloid gum kondagogu (Cochlospermum gossypium). Colloids Surf B Biointerfaces 83: 291-298. Link: https://bit.ly/3nX4NBd

37. Mittal AK, Chisti Y, Banerjee UC (2013) Synthesis of metallic nanoparticles using plant extracts. Biotechnology Advances 31: 346-356. Link: https://bit.ly/2LLwxvx

38. Aromal SA, Vidhu V, Philip D (2012) Green synthesis of well-dispersed gold nanoparticles using Macrotyloma uniflorum. Spectrochimica Acta Part A: Molecular and Biomolecular Spectroscopy 85: 99-104. Link: https://bit.ly/3qyNRCM

39. Kumar KP, Paul W, Sharma CP (2011) Green synthesis of gold nanoparticles with Zingiber officinale extract: characterization and blood compatibility. Process Biochemistry 46: 2007-2013. Link: https://bit.ly/3nUSplq

40. Tatur S, Maccarini M, Barker R, Nelson A, Fragneto G (2013) Effect of functionalized gold nanoparticles on floating lipid bilayers. Langmuir 29: 6606 6614. Link: http://bit.ly/3suGspV

41. Bansal SA, Kumar V, Karimi J, Singh AP, Kumar S (2020) Role of gold nanoparticles in advanced biomedical applications. Nanoscale Advances 2 3764-3787. Link: https://bit.ly/2LAU5n5

42. Singh P, Pandit S, Mokkapati V, Garg A, Ravikumar V, et al. (2018) Gold nanoparticles in diagnostics and therapeutics for human cancer. Int J Mol Sc 19: 1979. Link: https://bit.ly/3nUSs08

43. Gao Z, Zhang L, Sun YJJ (2012) Nanotechnology applied to overcome tumor drug resistance. J Control Release 162: 45-55. Link: http://bit.ly/38LzMfm

44. Shi P, Qu K, Wang J, Li M, Ren J, et al. (2012) pH-responsive NIR enhanced

Citation: Hussain S, Amjad M (2021) A Review on Gold Nanoparticles (GNPs) and their Advancement in Cancer Therapy. Int J Nanomater Nanotechnol Nanomed 7(1): 019-025. DOI: https://dx.doi.org/10.17352/2455-3492.000040 
drug release from gold nanocages possesses high potency against cancer cells. Chemical Communications 48: 7640-7642. Link: http://rsc.li/35I9VDe

45. Shi Y, Goodisman J, Dabrowiak JC (2013) Cyclodextrin capped gold nanoparticles as a delivery vehicle for a prodrug of cisplatin. 52: 9418-9426. Link: https://bit.ly/3bRjhQC

46. Rajeshkumar S (2016) Anticancer activity of eco-friendly gold nanoparticles against lung and liver cancer cells. J Genet Eng Biotechnol 14: 195-202. Link: http://bit.ly/38LCh14

47. Paciotti GF, Myer L, Weinreich D, Goia D, Pavel N, et al. (2004) Colloidal gold: a novel nanoparticle vector for tumor directed drug delivery. Drug Deliv 11: 169183. Link: http://bit.ly/3nO4Wai

48. Khiavi MA, Safary A, Barar J, Ajoolabady A, Somi MH, et al. (2020) Multifunctional nanomedicines for targeting epidermal growth factor receptor in colorectal cancer. Cell Mol Life Sci 77: 997-1019. Link: https://bit.ly/38WFon7

49. Jovčevska I, Muyldermans S (2020) The therapeutic potential of nanobodies. BioDrugs 34: 11-26. Link: https://bit.ly/35T06SS

50. Fard JK, Jafari S, Eghbal MAJA (2015) A review of molecular mechanisms involved in toxicity of nanoparticles. Adv Pharm Bull 5: 447-454. Link: http://bit.ly/38KkdVc

51. Kang MS, Lee SY, Kim KS, Han DW (2020) State of the art biocompatible gold nanoparticles for cancer theragnosis. Pharmaceutics 12: 701. Link: https://bit.ly/2KqRGdR

52. Simon HB (1993) Hyperthermia. N Engl J Med 329: 483-487. Link: http://bit.ly/2LPtFxv

53. FuJii J, Otsu K, Zorzato F, De Leon S, Khanna VK, et al. (1991) Identification of a mutation in porcine ryanodine receptor associated with malignant hyperthermia. Science 253: 448-451. Link: http://bit.ly/3suH7Yr

54. Hahn GM (2012) Hyperthermia and cancer: Springer Science \& Business Media.
55. Sharma, S. K., Shrivastava, N., Rossi, F., Tung, L. D., \& Thanh, N. T. K. (2019) Nanoparticles-based magnetic and photo induced hyperthermia for cancer treatment. Nano Today, 29, 100795.

56. Lee SH, Bae KH, Kim SH, Lee KR, Park TG (2008) Amine-functionalized gold nanoparticles as non-cytotoxic and efficient intracellular siRNA delivery carriers. Int J Pharm 364: 94-101. Link: http://bit.ly/2N98sPQ

57. Mohd-Zahid MH, Mohamud R, Abdullah CAC, Lim J, Alem H, et al. (2020) Colorectal cancer stem cells: a review of targeted drug delivery by gold nanoparticles. RSC Advances 10: 973-985.

58. Chithrani BD, Ghazani AA, Chan WC (2006) Determining the size and shape dependence of gold nanoparticle uptake into mammalian cells. Nano Lett 6 662-668. Link: http://bit.ly/3ij4lwb

59. Lim ZZ, Li JE, Ng CT, Yung LY, Bay BH (2011) Gold nanoparticles in cancer therapy. Acta Pharmacol Sin 32: 983-990. Link: http://bit.ly/3nK5CND

60. Ghosh P, Han G, De M, Kim CK, Rotello VM (2008) Gold nanoparticles in delivery applications. Adv Drug Deliv Rev 60: 1307-1315. Link: http://bit.ly/2LUjmbs

61. Ebrahimnezhad Z, Zarghami N, Keyhani M, Amirsaadat S, Akbarzadeh A et al. (2013) Inhibition of hTERT gene expression by silibinin-loaded PLGAPEG-Fe304 in T47D breast cancer cell line. Biolmpacts 3: 67-74. Link: http://bit.ly/3qq4AZ3

62. Borse VB, Konwar AN, Jayant RD, Patil PO (2020) Perspectives of characterization and bioconjugation of gold nanoparticles and their application in lateral flow immunosensing. Drug Deliv Transl Res 1-25. Link: https://bit.ly/2Kqa1Yu

63. Daraee H, Eatemadi A, Abbasi E, Fekri Aval S, Kouhi M, et al. (2016) Application of gold nanoparticles in biomedical and drug delivery. Artif Cells Nanomed Biotechnol 44: 410-422. Link: https://bit.ly/3ispOmj

\section{Discover a bigger Impact and Visibility of your article publication with}

\section{Peertechz Publications}

\section{Highlights}

* Signatory publisher of ORCID

* Signatory Publisher of DORA (San Francisco Declaration on Research Assessment)

* Articles archived in worlds' renowned service providers such as Portico, CNKI, AGRIS, TDNet, Base (Bielefeld University Library), CrossRef, Scilit, J-Gate etc.

* Journals indexed in ICMJE, SHERPA/ROMEO, Google Scholar etc.

* OAI-PMH (Open Archives Initiative Protocol for Metadata Harvesting)

* Dedicated Editorial Board for every journal

* Accurate and rapid peer-review process

Increased citations of published articles through promotions

* Reduced timeline for article publication

Submit your articles and experience a new surge in publication services (https://www.peertechz.com/submission).

Peertechz journals wishes everlasting success in your every endeavours.

Copyright: @ 2021 Hussain S, et al. This is an open-access article distributed under the terms of the Creative Commons Attribution License, which permits unrestricted use, distribution, and reproduction in any medium, provided the original author and source are credited.

Citation: Hussain S, Amjad M (2021) A Review on Gold Nanoparticles (GNPs) and their Advancement in Cancer Therapy. Int J Nanomater Nanotechnol Nanomed 7(1): 019-025. DOI: https://dx.doi.org/10.17352/2455-3492.000040 